\title{
Dyspepsia in children: organic or functional? Experience in a tertiary care hospital
}

\author{
Erick M. Toro-Monjaraz, ${ }^{*}$ Karen Ignorosa-Arellano, Karen Raya-Aguirre, Alejandro Loredo-Mayer, \\ Roberto Cervantes-Bustamante, Flora Zárate-Mondragón, José Cadena-León and \\ Jaime Ramírez-Mayans \\ Department of Gastroenterology and Pediatric Nutrition, Instituto Nacional de Pediatría, Mexico City, Mexico
}

\begin{abstract}
Introduction: Dyspepsia comprises a group of symptoms that can have organic or functional origin. The purpose of this study was to describe the main causes of dyspepsia and its clinical evolution in children cared for in a tertiary care hospital. Material and methods: Retrospective study in children with dyspepsia. Patients underwent endoscopy with biopsy and rapid urease test to detect the presence of Helicobacter pylori. In case of normal endoscopy and biopsy, hydrogen breath test was performed. In all cases, follow-up was provided in order to evaluate symptom improvement. Results: One hundred children were included, out of whom 52 were girls; mean age was 8.59 years. Esophagitis or erosive gastropathy were found in $54 \%$ of the cases $(n=54), H$. pylori infection in $12 \%(n=12)$, small intestinal bacterial overgrowth in $12 \%(n=12)$, and functional dyspepsia in 20\% $(n=20)$. Conclusion: In children with dyspepsia, organic causes should first be ruled out before dyspepsia being characterized as functional. In general terms, we consider that a stepped approach that includes endoscopy with biopsy, search for $\mathrm{H}$. pylori and hydrogen breath test is necessary.
\end{abstract}

KEY WORDS: Dyspepsia. Chronic abdominal pain. Children. Small intestinal bacterial overgrowth.

\section{Dispepsia en niños: ¿orgánica o funcional? Experiencia en un hospital de tercer nivel}

\section{Resumen}

Introducción: La dispepsia consiste en un conjunto de síntomas que pueden tener origen orgánico o funcional. El objetivo de este estudio fue describir las principales causas de la dispepsia y su evolución clínica en niños en un hospital de tercer nivel. Material y métodos: Estudio retrospectivo en niños con dispepsia. Los pacientes fueron sometidos a endoscopia con toma de biopsia y prueba de urea rápida para Helicobacter pylori. En caso de endoscopia y biopsia normal, se tomó prueba de hidrogeniones en aliento. En todos los casos se dio seguimiento para evaluar la mejoría de síntomas. Resultados: Se incluyeron 100 niños, de los cuales 52 eran niñas; la edad media fue de 8.59 años. Se encontró esofagitis y gastropatía erosiva en el $54 \%$ de los casos ( $n=54)$, infección por H. pylori en el 12\% $(n=12)$, sobrecrecimiento bacteriano del intestino delgado en el 12\% ( $n=12)$ y dispepsia funcional en el 20\% $(n=20)$. Conclusión: En niños con dispepsia se deben de descartar primero causas orgánicas antes de diagnosticar dispepsia funcional. En términos generales consideramos que es necesario un abordaje escalonado que incluya endoscopia con toma de biopsia, búsqueda de $\mathrm{H}$. pylori y una prueba de hidrogeniones.

PALABRAS CLAVE: Dispepsia. Dolor abdominal crónico. Niños. Sobrecrecimiento bacteriano del intestino delgado. 


\section{Introduction}

Acid peptic disease or dyspepsia is a clinical syndrome related to the upper gastrointestinal tract gastroduodenal region; symptoms include the presence or persistence of recurrent pain or discomfort in the epigastrium, early satiety, postprandial pain, nausea, pyrosis, belching or excessive hiccups, anorexia, weight loss, heartburn, periumbilical abdominal pain and regurgitation., ${ }^{1,2}$

The economic impact of caring for a patient with this pathology ranges from USD 699 to 724 annually, with the quality of life of patients and their families being affected. ${ }^{3-5}$

Dyspepsia can be the manifestation of organic, systemic or metabolic diseases, or have no apparent cause, as in functional dyspepsia. According to the Rome IV criteria, functional dyspepsia is defined as the presence of at least four days per month in the past two months of one or more of the following symptoms: postprandial fullness, early satiety, pain or burning in the epigastrium not associated with defecation. Thorough evaluation rules out other medical problems. ${ }^{6}$

The importance of knowing the main causes of dyspepsia lies in establishing proper diagnosis and treatment.

The main causes described in the pediatric population include: primary peptic ulcer disease; infectious agents such as Helicobacter pylori and other less common such as cytomegalovirus, herpes simplex virus, influenza A virus, Treponema pallidum, Candida albicans, histoplasmosis; hypersecretion states such as Zollinger-Ellison syndrome, medications such as non-steroidal analgesics, steroids, alcohol and valproic acid, among others. ${ }^{7}$

In Mexico, studies have been carried out in order to find out what are the causes of chronic abdominal pain in children, with organic causes being found as the main reasons for pain; however, in these studies, no difference was made between patient symptoms or follow-up to demonstrate symptom resolution..$^{8,9}$ The purposes of this study were to identify and describe the main causes of dyspepsia in Mexican children and adolescents cared for at a pediatric referral hospital in Mexico City, and to compare the improvement before and after an established treatment.

\section{Material and methods}

A retrospective, observational, analytical study was carried out in children with dyspepsia.
Dyspepsia was defined by one or more of the following symptoms: epigastric pain, sensation of early satiety, fullness, belching, burning sensation, continuous or intermittent nausea and vomiting at least four days a month during at least the two previous months.

Medical history and physical examination were performed on all children and a serial 3-sample stool testing was requested; in case of meeting dyspepsia criteria and no evidence of parasitosis in the stool tests, an endoscopy study of the upper gastrointestinal tract was performed, with biopsies of the duodenum, stomach and esophagus being taken after informed consent and/or assent was obtained. During the endoscopic procedure, all patients underwent a rapid urea test for $H$. pylori detection.

\section{Small intestinal bacterial overgrowth diagnosis}

In the absence of endoscopic data that justified the symptoms, a hydrogen breath test was performed with the Gastrolyzer ${ }^{\circledR}$ equipment, with the following specifications: discontinuation of proton pump inhibitors or any antacid at least two weeks prior to the test. This test was carried out on fasting conditions, and the patient was administered $0.5 \mathrm{~g} / \mathrm{kg}$ of lactulose (up to $10 \mathrm{~g}$ ), with measurements being made every $20 \mathrm{~min}$ utes for 3 hours. The test for small intestinal bacterial overgrowth (SIBO) was considered positive when an increase from baseline of more than $20 \mathrm{ppm}$ with was observed before minute 90 .

\section{Helicobacter pylori diagnosis}

Gastric biopsies were taken according to the Sydney protocol and were evaluated with a rapid urease test and histological examination. $H$. pylori infection was defined by two positive invasive tests, in accordance with the latest guidelines published for children. ${ }^{10}$

All patients with evidence of severe inflammation in the upper gastrointestinal tract (esophagitis, duodenitis, gastritis and ulcer) received a proton pump inhibitor for four weeks and, if necessary, sucralfate $80 \mathrm{mg} /$ $\mathrm{kg} /$ day was added, and control endoscopy was performed at the end of treatment.

Patients with SIBO were treated with rifaximin for seven days and probiotics (Saccharomyces boulardii or Lactobacillus GG) for two weeks. The group of 
SIBO-positive patients underwent a control hydrogen breath test six weeks later.

Patients with a positive result for $\mathrm{H}$. pylori infection received standard treatment (amoxicillin $50 \mathrm{mg} / \mathrm{kg}$ / day, clarithromycin $15 \mathrm{mg} / \mathrm{kg} /$ day, and a proton pump inhibitor daily for 15 days). To assess $H$. pylori eradication, in addition to clinical evaluation, a carbon 13-labeled urea breath test was performed.

We considered functional dyspepsia according to the Rome IV criteria in all children with the above-described symptoms and normal endoscopy, negative hydrogen breath test, and no $H$. pylori infection. Treatment for this entity included proton pump inhibitors, prokinetics, and assessment by the Mental Health Department.

\section{Results}

Of the 100 subjects, 52 were girls and 48 were boys; mean age was 8.59 years, 49 children were eutrophic according to their body mass index. Patient demographic characteristics are shown in table 1. As for the diagnoses that were established, combined esophagitis and erosive gastropathy corresponded to $54 \%(n=54)$ of the cases (Table 2), followed by functional dyspepsia in $20 \%$ of cases, while bacterial overgrowth and $H$. pylori infection accounted for $12 \%$ each, with peptic ulcer only being found in two cases, which were not associated with $H$. pylori.

Regarding the symptoms, early satiety was the predominant symptom (75\%), followed by anorexia (65\%) and epigastric pain (59\%); however, according to the etiological diagnosis, symptoms were different: the children that were diagnosed with esophagitis had anorexia $(71 \%)$ and epigastric pain (66\%) as predominant symptoms. In the case of functional dyspepsia, predominant symptoms were early satiety, abdominal distension and epigastric pain; in the children with H. pylori, early satiety and epigastric pain were more common and, finally, in the children with SIBO, diffuse periumbilical pain, early satiety and anorexia predominated (Table 3 ).

As for symptomatology, there was an improvement of $76 \%$ in the entire population with specific treatment for each pathology.

Patients with SIBO had an improvement of $91 \%$ $(p=0.029)$, while in those with erosive esophagitis, improvement was observed in $75.5 \%(p=0.008)$; in cases of functional dyspepsia, an improvement of $80 \%$ was recorded $(p=0.018)$ and, finally, patients with $H$. pylori infection had an improvement of $66.6 \%$ $(p=0.029)$ (Table 4).
Table 1. Participants' general characteristics

\begin{tabular}{|l|c|}
\hline Variable & $\mathrm{n}=100 \%$ \\
\hline $\begin{array}{l}\text { Gender } \\
\text { Females } \\
\text { Males }\end{array}$ & 48 \\
\hline Age (mean) & 58 \\
\hline BMI & 8.59 (2-14 years) \\
Nutritional status & 18.49 \\
Eutrophic & \\
Undernutrition & \\
Overweight & 49 \\
Obesity & 14 \\
\hline
\end{tabular}

BMI: body mass index.

Table 2. Diagnosis of patients with dyspepsia

\begin{tabular}{l|c|}
\hline Diagnosis & $\mathrm{n}=100 \%$ \\
\hline Erosive esophagitis & 45 \\
Functional dyspepsia & 20 \\
SIBO & 12 \\
Helicobacter pylori & 12 \\
Erosive gastropathy & 9 \\
Ulcer & 2
\end{tabular}

SIBO: small intestinal bacterial overgrowth.

\section{Discussion}

Dyspepsia is a group of symptoms that can represent different diseases. Previous studies have evaluated the etiology of these symptoms. Hyams et al. carried out a study in 127 children, out of whom only 56 underwent endoscopy according to the treating physician criteria, with a prevalence of functional dyspepsia being found in $62 \%$ of this subgroup, and the rest having some endoscopic finding that justified the pain. ${ }^{11}$ In our study, we documented endoscopic findings (erosive gastropathy, esophagitis) that justified the symptoms in $54 \%$ of the children, although this figure was lower than that reported by Adeniyi et al. in Lagos (Nigeria), where they documented endoscopic findings in $87 \%$ of the children and adolescents who attended with data consistent with dyspepsia. ${ }^{12}$ In our patients, after established management, there was symptom improvement in $75 \%$ of the children who presented with esophagitis and only in $50 \%$ of those who presented with erosive gastropathy. 
Table 3. Description of symptoms according to the diagnosis

\begin{tabular}{|c|c|c|c|c|c|c|c|}
\hline Symptoms & $\begin{array}{l}\text { Erosive esophagitis } \\
45\end{array}$ & $\begin{array}{c}\text { Functional } \\
\text { dyspepsia } \\
20\end{array}$ & $\begin{array}{c}\text { SIBO } \\
12\end{array}$ & $\begin{array}{c}\text { Helicobacter pylori } \\
12\end{array}$ & $\begin{array}{c}\text { Erosive } \\
\text { gastropathy } \\
9\end{array}$ & $\begin{array}{l}\text { Ulcer } \\
2\end{array}$ & $\begin{array}{c}\text { Total } \\
100\end{array}$ \\
\hline Epigastric pain & $30(66.6 \%)$ & $16(85 \%)$ & $2(16.6 \%)$ & $8(66.6 \%)$ & $2(22.2 \%)$ & $1(50 \%)$ & 59 \\
\hline Periumbilical abdominal pain & $15(33.3 \%)$ & $4(25 \%)$ & $10(83 \%)$ & $4(33.3 \%)$ & $7(77.7 \%)$ & $1(50 \%)$ & 41 \\
\hline Nausea & $13(28.8 \%)$ & $6(30 \%)$ & $4(33.3 \%)$ & $6(50 \%)$ & $3(33.3 \%)$ & $1(50 \%)$ & 33 \\
\hline Vomiting & $11(24.4 \%)$ & $5(25 \%)$ & $3(25 \%)$ & $3(25 \%)$ & $2(22.2 \%)$ & 0 & 24 \\
\hline Early satiety & $29(64.4 \%)$ & $18(90 \%)$ & $10(83 \%)$ & $9(75 \%)$ & $7(77.7 \%)$ & $2(100 \%)$ & 75 \\
\hline Belching & $14(31.1 \%)$ & $15(75 \%)$ & $5(41.6 \%)$ & $4(33 \%)$ & $3(33.3 \%)$ & $1(50 \%)$ & 42 \\
\hline Anorexia & $32(71.1 \%)$ & $13(65 \%)$ & $11(91.6 \%)$ & $2(16.6 \%)$ & $6(66.6 \%)$ & $1(50 \%)$ & 5 \\
\hline Abdominal distension & $20(44.4 \%)$ & $18(90 \%)$ & $9(75 \%)$ & $5(41.6 \%)$ & $2(22.2 \%)$ & 0 & 54 \\
\hline
\end{tabular}

Table 4. Symptom improvement with specific treatment

\begin{tabular}{|l|c|c|}
\hline Diagnosis & Improvement & $p$ \\
\hline Erosive esophagitis & $34(75.5 \%)$ & 0.008 \\
\hline Functional dyspepsia & $16(80 \%)$ & 0.018 \\
\hline SIBO & $11(91 \%)$ & 0.029 \\
\hline Helicobacter pylori & $8(66.6 \%)$ & 0.029 \\
\hline Erosive gastropathy & $6(55.5 \%)$ & 0.06 \\
\hline Ulcer & $2(100 \%)$ & 0.09 \\
\hline SIBO: small intestinal bacterial overgrowth. & & \\
\hline
\end{tabular}

$H$. pylori is a cause of dyspeptic symptoms; howev$\mathrm{er}$, its frequency in children and causality relationship with abdominal pain is a topic of discussion. In a systematic review of 38 articles, no association was found between gastrointestinal symptoms in children and $H$. pylori in patients attending primary care; however, there was an association between epigastric pain and $H$. pylori infection in six in-hospital studies, with a pooled odds ratio of 2.87 (95\% confidence interval: $1.62-5.09) .^{13}$

In our study, $H$. pylori was diagnosed with two tests (rapid urea test and biopsy) in $12 \%$ of patients; early satiety and epigastric pain were the most common symptoms in this group of patients $(75$ and $66 \%$ respectively), with improvement after eradication occurring in $66 \%$ of the children; this can be explained by resistance to the antibiotics that were used or even by the fact that this bacterium may not have been responsible for the symptoms. Other studies have evaluated the role H. pylori plays in the development of dyspeptic symptoms. Farrell et al. found symptom improvement in children in whom $H$. pylori was eradicated and, in most of them, long-term improvement. ${ }^{14}$ Another study carried out in Turkey also showed dyspeptic symptoms' improvement in the group of patients who had $H$. pylori eradicated. ${ }^{15}$ We consider that given the demonstrated evidence, if $H$. pylori is diagnosed by invasive methods, eradication treatment is necessary, although probably it is not the main cause of dyspepsia in children.

SIBO has been described as a cause of irritable bowel syndrome in adults, and recently has also been identified as a cause of dyspepsia; ${ }^{16,17}$ however, in children there are few studies that have associated SIBO with chronic abdominal pain. ${ }^{18}$ As far as we know, this is the first study carried out in children where dyspepsia has been associated with SIBO. In a recent study in patients with functional gastrointestinal disorders (FGIDs), healthy controls and subjects with inflammatory bowel disease, using a biopsy device with aseptic technique and with bacterial load being quantified by means of quantitative polymerase chain reaction, an elevated number of bacteria was found in the duodenum of patients with FGIDs in comparison with healthy subjects, and only $15 \%$ were positive in the hydrogen breath test with glucose and $13.3 \%$ with methane, which shows that the hydrogen breath test does not necessarily reflect what happens with the number of bacteria in the duodenum in SIBO..$^{19}$ In our study, we found that $12 \%$ (12 children) of the children had SIBO and, after treatment, $90 \%$ of them (11 children) improved, which opens a new possibility in the etiology of dyspepsia in children and, necessarily, to its research and verification. 
As for the explanation on why SIBO causes dyspepsia, Tziatzios et al. summarize it as a cascade of events that results in transmural inflammation, myenteric ganglionitis, dysmotility and visceral hyperalgesia secondary to an excessive presence of bacteria in the small intestine. ${ }^{20}$ This study allows an approach to the main causes of dyspepsia in a tertiary care hospital, which may differ from what can be observed in a primary care center; however, it allows priorities to be established in diagnostic methods and the treatment employed to avoid unnecessary procedures. The weaknesses of this study are that a standardized treatment was not used in all children with esophagitis or erosive gastropathy and functional dyspepsia, which may bias the follow-up result; however, it opens the discussion on the role played by SIBO in the development of dyspepsia in children.

\section{Conclusion}

Dyspepsia in children continues to be a subject that requires further investigation; however, in accordance with the findings of our study, we consider that organic causes should be ruled out first before classifying the child with functional dyspepsia. In general terms, we consider that a stepwise approach is necessary, which should include endoscopy with biopsy, search for $H$. pylori and a hydrogen breath test.

\section{Funding}

This study did not receive any funding.

\section{Conflict of interests}

The authors of this study declare that they have no conflicts of interest.

\section{Ethical disclosures}

Protection of human and animal subjects. The authors declare that the procedures that were followed adhered to the ethical standards of the responsible committee for experimentation on human beings and were in agreement with the World Medical Association and the Declaration of Helsinki.

Confidentiality of data. The authors declare that they have followed the protocols of their work center on the publication of patient data.
Right to privacy and informed consent. The authors have obtained informed consent from the patients and/or subjects referred to in the article. This document is in the possession of the corresponding author.

\section{References}

1. Tack J, Talley NJ. Functional dyspepsia-symptoms, definitions and validity of the Rome III criteria. Nat Rev Gastroenterol Hepatol. 2013:10:134-41.

2. Tack J, Talley NJ, Camilleri M, Holtmann G, Hu P, Malagelada JR, et al. Functional gastroduodenal disorders. Gastroenterology. 2006;130:1466-79.

3. Mani J, Madani S, Thomas R. Economic impact and prognostic factors of functional dyspepsia in children. J Pediatr Gastroenterol Nutr. 2020;70(4):e65ロe70.

4. Lewis ML, Palsson OS, Whitehead WE, van Tilburg MAL. Prevalence of functional gastrointestinal disorders in children and adolescents. J Pediatr. 2016;177:39ロ43.e3.

5. Lacy BE, Weiser KT, Kennedy AT, Crowell MD, Talley NJ. Functional dyspepsia: the economic impact to patients. Aliment Pharmacol Ther. 2013;38(2):17007.

6. Rasquin A, Di Lorenzo C, Forbes D, Guiraldes E, Hyams JS, Staiano A, et al. Childhood functional gastrointestinal disorders: child/adolescent. Gastroenterology. 2006;130(5):1527ロ37.

7. Kleinman R, Goulet O, Mieli-Vergani G, Sanderson I, Sherman P, Shneider B, editors. Walker's Pediatric Gastrointestinal Disease. Vol. 1. People's Medical Publishing House; 2018. pp. 153-161.

8. Ocampo del Prado L, Cervantes Bustamante R, Ramírez Mayans JA Dolor abdominal crónico recurrente en niños. Acta Pediatr Mex. 2003;24(6):351-3

9. Méndez Nieto CM, Ramírez-Mayans J, Cervantes R, Mata N, Cuevas F, Martínez C, et al. Diagnóstico de Helicobacter pylori en niños con dolor abdominal recurrente. Acta Gastroent Latinoamer. 1994;24:169-74.

10. Jones NL, Koletzko S, Goodman K, Bontems P, Cadranel S, Casswall T, et al. Joint ESPGHAN/NASPGHAN Guidelines for the Management of Helicobacter pylori in Children and Adolescents (Update 2016). J Pediatr Gastroenterol Nutr. 2017;64(6):99101003.

11. Hyams JS, Davis P, Sylvester FA, Zeiter DK, Justinich CJ, Lerer T. Dyspepsia in children and adolescents: a prospective study. J Pediatr Gastroenterol Nutr. 2000;30(4):413ロ8.

12. Adeniyi OF, Odeghe EA, Lawal MA, Olowu AO, Ademuyiwa A. Recurrent abdominal pain and upper gastrointestinal endoscopy findings in children and adolescents presenting at the Lagos University Teaching Hospital. PLoS One. 2019;14(5):e0216394.

13. Spee LA, Madderom MB, Pijpers M, van Leeuwen Y, Berger MY. Association between Helicobacter pylori and gastrointestinal symptoms in children. Pediatrics. 2010;125(3):e651[e669.

14. Farrell S, Milliken I, Murphy JL, Wootton SA, McCallion WA. Non ulcer dyspepsia and Helicobacter pylori eradication in children. J Pediatr Surg. 2005;40(10):1547ロ50.

15. Ünlüsoy Aksu A, Yılmaz G, Eğritaş Gürkan Ö, Sarı S, Dalgıç B. The effect of Helicobacter pylori eradication on functional dyspepsia in Turkish children. Helicobacter. 2018;23(4):e12497.

16. Petzold G, Amanzada A, Gress TM, Ellenrieder V, Neesse A, Kunsch S High prevalence of pathological hydrogen breath tests in patients with functional dyspepsia. Digestion. 2019;100(3):186-91.

17. Shimura S, Ishimura N, Mikami H, Okimoto E, Uno G, Tamagawa Y, et al. Small intestinal bacterial overgrowth in patients with refractory functional gastrointestinal disorders. J Neurogastroenterol Motil. 2016;22(1):60-8.

18. Avelar Rodríguez D, Ryan PM, Toro Monjaraz EM, Ramírez Mayans JA Quigley EM. Small intestinal bacterial overgrowth in children: A state-ofthe-art review. Front Pediatr. 2019;7:363.

19. Shah A, Talley NJ, Koloski N, Macdonald GA, Kendall BJ, Shanahan ER, et al. Duodenal bacterial load as determined by quantitative polymerase chain reaction in asymptomatic controls, functional gastrointestinal disorders and inflammatory bowel disease. Aliment Pharmacol Ther. 2020;52(1):155-67.

20. Tziatzios G, Giamarellos-Bourboulis EJ, Papanikolaou IS, Pimentel M, Dimitriadis GD, Triantafyllou K. Is small intestinal bacterial overgrowth involved in the pathogenesis of functional dyspepsia? Med Hypotheses. 2017:106:26-32. 